\title{
The status of serum vitamin $D$ in the population of the United Arab Emirates
}

K. Yammine ${ }^{1}$ and H. Al Adham ${ }^{2}$

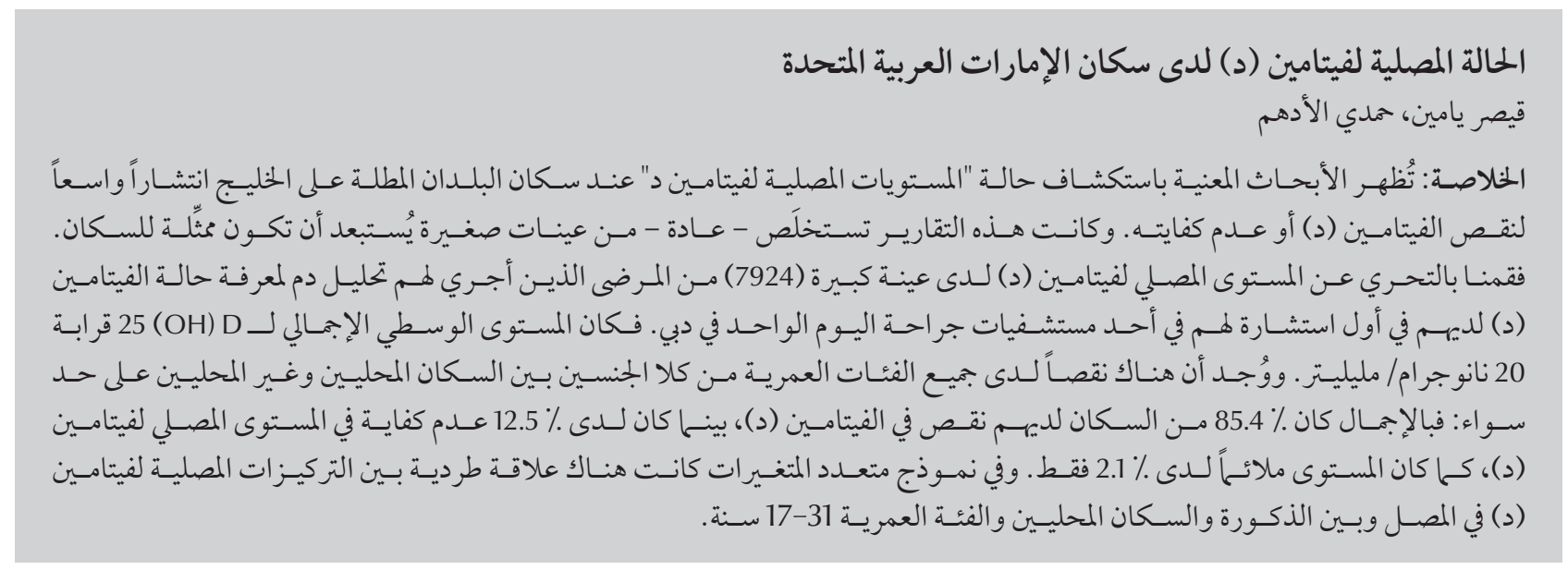

ABSTRACT Research exploring the status of serum vitamin D levels in the populations of countries bordering the Arabian Gulf shows a high prevalence of vitamin D deficiency/insufficiency. These reports were usually drawn from small samples unlikely to be representative of the population. We explored serum vitamin D level in a large sample (7924) of patients who were given a blood test to check their vitamin D status on their first consultation at a day surgery hospital in Dubai. The overall mean level of $25(\mathrm{OH}) \mathrm{D}$ was $\sim 20 \mathrm{ng} / \mathrm{mL}$ Deficiency was found among all age groups, in both sexes and in both local and non-local populations: overall $85.4 \%$ were vitamin D deficient, $12.5 \%$ showed insufficient serum vitamin D level, and only $2.1 \%$ had an appropriate level. In the multivariate model, serum vitamin D concentrations were positively correlated with male sex, local population and the 17-31 years age group.

\section{Statut en vitamine D sérique de la population des Émirats arabes unis}

RÉSUMÉ Les travaux de recherche se penchant sur le statut des concentrations sériques de vitamine D dans les populations des pays bordant le Golfe arabique montrent une forte prévalence de la carence/I'insuffisance en vitamine D. Ces rapports s'appuyaient habituellement sur de petits échantillons qui n'étaient certainement pas représentatifs de la population. Nous avons étudié la concentration en vitamine D dans un grand échantillon de patients (7924) qui ont été soumis à un examen sanguin pour vérifier leur statut en vitamine D lors de leur première consultation dans un hôpital chirurgical de jour de Dubaï. La concentration moyenne globale de 25(OH) D était d'environ $20 \mathrm{ng} / \mathrm{mL}$. Une carence a été observée dans tous les groupes d'âge, pour les deux sexes et dans les populations locales et non locales. Globalement, 85,4\% d'entre eux avaient une carence en vitamine D, 12,5\% montraient une concentration sérique en vitamine D insuffisante, et seulement 2,1\% avaient une concentration adéquate. Dans le modèle multivarié, les concentrations sériques de vitamine D avaient une corrélation positive avec le sexe masculin, la population locale et le groupe d'âge des 17-31 ans.

${ }^{7}$ Foot and Hand Clinic, Center for Evidence-Based Anatomy, Sport and Orthopaedic Research, Beirut, Lebanon (Correspondence to: K. Yammine: kayseryam@yahoo.com). ${ }^{2}$ Administration Department, Emirates Hospital, Dubai, United Arab Emirates.

Received: 29/03/15; accepted:03/08/16 


\section{Introduction}

The role of vitamin D $(25(\mathrm{OH}) \mathrm{D})$ in maintaining optimal health has been well documented and deficiency has been linked to a spectrum of conditions such as autoimmune disorders, cancer, osteoporosis, cardiovascular disease and obesity (1). Epidemic low levels are reported from around the globe, regardless of sex and age (2-4). Besides a suboptimal consumption of foods containing vitamin D such as fish and fortified milk, limited sun exposure is considered the major cause of vitamin D deficiency (4). Populations at risk are mainly those having minimal outdoor activities such as indoor workers and students. Extensive clothing or extensive sunscreen application are also considered major risk factors $(2,5,6)$.

Reports of prevalence of vitamin $\mathrm{D}$ insufficiency/deficiency in countries bordering the Persian Gulf are indicative of a serious health issue (7-9). Vitamin D insufficiency (30-50 ng/ $\mathrm{mL}$ ) has been reported in up to $80 \%$ of Saudi Arabian girls and women (10) and Kuwaiti women (11), and in up to $90 \%$ of the population of Qatar (12) and the female population in the United Arab Emirates (13). The United Arab Emirates has an average of 10 hours of sunshine per day, which should favour vitamin $\mathrm{D}$ synthesis all year round $(2,14)$.

Many studies on vitamin D status have been published from universities and research centres in the United Arab Emirates (14-21). In all those studies, sample size was generally too small for an accurate estimation of the prevalence of vitamin D insufficiency/deficiency in the population.

Population-based data on the status of vitamin D in the United Arab Emirates are lacking. Therefore, the aim of this retrospective study was to generate overall, sex-based, age-based and nationality-based prevalence estimates of vitamin D status among the local population and the residents of Dubai from a very large sample.

\section{Methods}

\section{Setting}

This cross-sectional retrospective study was conducted at Emirates Hospital, a day surgery hospital in Dubai where almost all surgeries are elective. In addition to surgical specialties, medical expertise such endocrinology, internal medicine, dermatology and cardiology are available. The hospital is located in an urban community and patients' nationalities reflect the wide diversity of the Dubai population.

The study was approved by the ethical committee of the institution.

\section{Sample and data extraction}

Data values for $25(\mathrm{OH}) \mathrm{D}$ level tested at the first medical consultation were collected retrospectively from the hospital laboratory's information system between February 2012 and January 2014. Blood results at follow-up consultations were excluded. The clinical rationale for the blood test was not retrieved, nor was the specialty of the treating doctor.

\section{Blood testing and measurement}

We used serum 25(OH) D level as an indicator of vitamin D status (22). Blood specimen collection and analysis are done systematically at the hospital and follow rigorous protocols. Blood samples were sent to the laboratory within 30 minutes of drawing, where they underwent standardized (quality controlled) analyses, blood clotting for 30 minutes followed by centrifugation for 20 minutes. Serum 25(OH) D concentrations were measured by immunofluorescence (Liaison XL) with a cut-off level for 25(OH) D of < $30 \mathrm{ng} /$ $\mathrm{mL}$ (1). Vitamin D status was defined as: deficiency $25(\mathrm{OH}) \mathrm{D}<30 \mathrm{ng} / \mathrm{mL}$; insufficiency $30-50 \mathrm{ng} / \mathrm{mL}$; and sufficiency $>50 \mathrm{ng} / \mathrm{mL}$.

\section{Outcomes}

The overall vitamin $\mathrm{D}$ mean value in our sample was set as the first primary outcome. Other primary outcomes were the mean values related to age, nationality and sex. We defined 2 nationality groups: the local group, which comprised patients with United Arab Emirates nationality and the non-local group comprising all other nationalities. We divided our sample into 4 age categories ( $1-16$ years, $17-31$ years, $32-46$ years and $47-92$ years).

We did not include body mass index (BMI) as a variable because weight is not documented in the system.

As a secondary outcome, we searched for any correlation between vitamin D serum levels and each of our 3 predefined variables.

\section{Data analysis}

The overall mean values for $25(\mathrm{OH}) \mathrm{D}$ for each variable were first computed. Then the Pearson test was used to investigate any correlation. We used simple and multiple linear regression tests to look for possible relationships. Two-tailed $P$-values were recorded and $P$-value $<0.05$ was considered statistically significant. Statistical operations were done using StatsDirect, version 2.7.8 (Altrincham, United Kingdom).

\section{Results}

\section{Demographic characteristics}

Vitamin D results were retrieved from a total of 7924 patients attending their first consultation at the hospital (Table 1). A large proportion of the patients in our sample, 6787 (85.8\%), were nonlocal, i.e. of various nationalities. Patients aged 32-46 years made up largest age group, 4097 (51.7\%). Overall mean age was 37 years 


\section{Overall and variable-based mean values of vitamin $D$}

The overall mean serum vitamin $\mathrm{D}$ level was 19.9 [standard deviation (SD) 11.3] ng/mL (Table 1). The lower quartile was $11.9 \mathrm{ng} / \mathrm{mL}$ and the upper quartile was $25.2 \mathrm{ng} / \mathrm{mL}$. The youngest and oldest age groups had the highest mean vitamin $\mathrm{D}$ values (Table 1 ). Vitamin D level was $\geq 30 \mathrm{ng} / \mathrm{mL}$ among $13.7 \%$ of the males in our sample and $15.2 \%$ of the females.

We found that $1384(17.5 \%)$ patients had vitamin levels $\leq 10 \mathrm{ng} / \mathrm{mL}$, 3176 (40\%) having $10<25(\mathrm{OH}) \mathrm{D} \leq$ 20, 2207 (27.8\%) patients having $20<$ $25(\mathrm{OH}) \mathrm{D} \leq 30,757$ (9.6\%) patients having $30<25(\mathrm{OH}) \mathrm{D} \leq 40,239(3 \%)$ patients having $40<25(\mathrm{OH}) \mathrm{D} \leq 50$, $96(1.2 \%)$ patients having $50<25(\mathrm{OH})$ $\mathrm{D} \leq 60$, and $64(0.9 \%)$ patients having $25(\mathrm{OH}) \mathrm{D}>60$. Thus, 6767 (85.4\%) were vitamin D deficient, 996 (12.5\%) had an insufficient level of vitamin D, and only $160(2.1 \%)$ had an appropriate serum vitamin D level (Table 1).

\section{Correlation with gender, ancestry and age}

Correlation with sex of the patient yielded a significant difference between males and females: males had lower serum vitamin $\mathrm{D}$ levels than females ( $r=$ 0.028, CI: $0.006-0.050, P=0.01$ ). Correlation with nationality yielded a highly significant difference between local and non-local populations: the local population showed lower serum vitamin D levels than the non-local $(r=0.11, \mathrm{CI}$ : $0.093-0.136, P=<0.0001)$. Correlation with age also yielded highly significant differences in relation to age group $(r=$ 0.08, CI: $0.057-0.101, P<0.0001)$. The mean level of serum vitamin $\mathrm{D}$ in our youngest age group, where the majority were above the age of 8 years, was 22.3 $\mathrm{ng} / \mathrm{mL}$

A multiple regression test including all 3 variables yielded $r^{2}=2 \%(r=0.14$, $P<0.0001)$. Age group of $17-31$, males and locals yielded positive correlation in the model. A summary of the regression analysis results are given in Table 2.

\section{Discussion}

\section{Summary and interpretation of main results}

To our knowledge, it is the first study carried out in the United Arab Emirates with such a large size sample. The majority of the population in this study were vitamin D deficient (overall mean $\approx 20 \mathrm{ng} / \mathrm{mL}$ ), and this was seen in all age groups and in both sexes. The results indicate an alarming serum vitamin D level among the population when compared with other Emirati reports (13-21), with just around 2\% of patients attending their first consultation showing an appropriate level. For instance, the mean level of vitamin D in our paediatric population, where the majority were above the age of 8 years, was $22.3 \mathrm{ng} / \mathrm{mL}$, reflecting a deficiency when compared with the insufficient value of $35.3 \mathrm{ng} / \mathrm{mL}$ reported by Rajah et al. among 48 children in the same age group living in Abu Dhabi (20). Furthermore, out of a sample of 315 healthy adolescents residing in $\mathrm{Al}$ Ain city, Muhairi et al. reported vitamin D concentration of less than $25 \mathrm{ng} / \mathrm{mL}$ in $65 \%(23)$.

\begin{tabular}{|c|c|c|c|c|c|}
\hline \multirow[t]{2}{*}{ Variable } & \multirow[t]{2}{*}{ No. (\%) } & \multirow{2}{*}{$\begin{array}{c}25(\mathrm{OH}) \mathrm{D} \text { mean }(\mathrm{SD}) \\
\mathrm{ng} / \mathrm{mL}\end{array}$} & \multicolumn{3}{|c|}{ Correlation } \\
\hline & & & $r$ value & $\mathrm{Cl}$ & $P$ \\
\hline Total & $7924(100)$ & $19.9(11.3)$ & NA & NA & NA \\
\hline Males & 2418 (30.5) & $20.6(11.3)$ & \multirow{2}{*}{0.028} & \multirow{2}{*}{$0.006-0.050$} & \multirow{2}{*}{0.01} \\
\hline Females & $5506(69.5)$ & 19.8 (11.29) & & & \\
\hline Locals & $1137(14.3)$ & 19.1 (11.1) & \multirow{2}{*}{0.110} & \multirow{2}{*}{$0.093-0.136$} & \multirow{2}{*}{0.0001} \\
\hline Non-locals & $6787(85.7)$ & $20.07(11.3)$ & & & \\
\hline \multicolumn{6}{|l|}{ Age (years) } \\
\hline $0-16$ & $425(5.3)$ & $22.3(0.1)$ & \multirow{4}{*}{0.080} & \multirow{4}{*}{$0.057-0.101$} & \multirow{4}{*}{$<0.0001$} \\
\hline $17-31$ & $1944(24.5)$ & $17.8(11.4)$ & & & \\
\hline $32-46$ & 4097 (51.7) & $19.8(11.0)$ & & & \\
\hline$>47$ & $1458(18.4)$ & $22.1(11.5)$ & & & \\
\hline \multicolumn{6}{|c|}{$25(\mathrm{OH}) \mathrm{D}(\mathrm{ng} / \mathrm{mL})$} \\
\hline$<30$ & $6767(85.4)$ & NA & NA & NA & NA \\
\hline $30-50$ & $996(12.5)$ & NA & NA & NA & NA \\
\hline$>50$ & $161(2.1)$ & NA & NA & NA & NA \\
\hline
\end{tabular}

$N A=$ not appropriate 


\begin{tabular}{|c|c|c|c|}
\hline Variable & Equation & Two-sided $P$ & Notes \\
\hline Age & Result $=0.07094$ age +17.283366 & $<0.0001$ & NA \\
\hline Sex & Result $=0.691757$ sex +19.454921 & 0.01 & $\begin{array}{l}\text { Male }=0 \\
\text { Female }=1\end{array}$ \\
\hline Nationality & Result $=3.717087$ local +16.747169 & $<0.0001$ & $\begin{array}{l}\text { Non-local }=1 \\
\text { Local }=0\end{array}$ \\
\hline Age + sex + nationality & $\begin{array}{l}\text { Result }=13.465351+0.900458 \text { sex }+3.745023 \text { Local } \\
+0.070404 \text { age }\end{array}$ & $<0.0001$ & NA \\
\hline
\end{tabular}

$N A=$ not appropriate

Our results showed that vitamin D deficiency was significantly associated with the 17-31 years age group, males and Emirati nationality. None of the variables was found to be a confounder; the coefficient associated with each variable in simple linear regression tests did not change significantly from that found in the multiple linear regression tests for each variable. The number of females in our study sample was significantly higher than males ( $70 \%$ female, $30 \%$ male); we found that deficiency was associated with male sex, emphasizing the epidemic aspect of the deficiency. In this part of the world where osteoporosis and vitamin $\mathrm{D}$ deficiency are mostly investigated among women, this study should encourage physicians to consider this issue as highly prevalent in men, and our findings provide a rationale for mass screening among the male population as well as females.

Although we found a significant correlation between each of those variable and mean $25(\mathrm{OH})$ D level, the multiple linear regression test yielded an $\mathrm{r}^{2}$ of only $2 \%$, meaning that only $2 \%$ of the variations in $25(\mathrm{OH}) \mathrm{D}$ values is explained by this model. This result is in accordance with current knowledge, i.e. that the most important variable for an appropriate vitamin $\mathrm{D}$ blood level is sun exposure (20).

It is hoped the results of this study will encourage decision-makers to tackle this treatable medical condition, and efforts should be coordinated at the highest national level. While sun exposure is the main source of vitamin $\mathrm{D}$, countermeasures for preventing deficiency and maintaining an appropriate serum level among residents should be within reach in this sunny country.

\section{Limitations}

A possible limitation in this study is the lack of information regarding the clinical presentation of the patients. However, the correlation between the clinical presentation and serum $25(\mathrm{OH}) \mathrm{D}$ level was not within the scope of the study. In fact, our findings indicate that for whatever clinical reason, a great majority of patients who seek medical advice for the first time are $25(\mathrm{OH})$ $\mathrm{D}$ deficient; the upper quartile of the overall mean value was 25.2. Moreover, it is very likely that a number of these patients were examined and treated some time in their life in other health care facilities. Therefore, the mean values generated in our study could be even lower if data on such patients were not included. This fact should alert health care professionals of the seriousness of issues such as non-compliance or lack of awareness of the role of vitamin $D$ in maintaining optimal health by patients in this region of the world.

Since a statistical estimate drawn from a larger sample will reflect more accurately the true estimate in a population, the difference between sex-based prevalence values found in this study could be biased since the number of females in the sample was double the number of males. However, the results indicate that vitamin $\mathrm{D}$ deficiency among males is at least as prevalent as in females.

Due to its predefined limited scope, this study did not check for other potential risk factors such as diet and sun exposure. We could not verify the nationalities of the non-local population to look for any differences within that group. Additionally, the study was conducted in a private hospital in Dubai where mostly insured patients access the medical care. On the other hand, due to the settings of our institution, our relatively young patients, $82 \%$ under 46 years, very seldom have severely impaired health conditions such as chronic renal or liver failure, which could result in decreased conversion to the active form of vitamin D (24). Checking for vitamin $\mathrm{D}$ level is very commonly requested by both patients and doctors in our hospital. Furthermore, it is difficult to distinguish between healthy people and patients in regard to this condition; as mentioned above, previous studies have reported frequencies of up to $90 \%$ vitamin D deficiency/insufficiency in "healthy" subjects $(12,13)$.

Nevertheless, although our results may not be generalizable to the whole population of the United Arab Emirates, the large sample size should reduce the impact of this limitation to a minimum.

\section{Funding: None.}

Competing interests: None declared 


\section{References}

1. Holick MF. Vitamin D status: measurement, interpretation and clinical application. Ann Epidemiol. 2009 Feb;19(2):73-8. PMID:18329892

2. Holick MF. Sunlight and vitamin D for bone health and prevention of autoimmune diseases, cancers, and cardiovascular disease. Amer J Clin Nutr. 2004 Dec;80(6 Suppl.):1678S-88S. PMID:15585788

3. Holick MF. The vitamin D epidemic and its health consequences. J Nutr. 2005 Nov;135(11):2739S-48S. PMID:16251641

4. Holick MF, Binkley NC, Bischoff-Ferrari HA, Gordon CM, Hanley DA, Heaney RP, et al. Evaluation, treatment, and prevention of vitamin D deficiency: an Endocrine Society Clinical Practice Guideline. J Clin Endocrinol Metab. 2011 Jul; 96(7):1911-30. PMID:21646368

5. Glerup H, Mikkelsen K, Poulsen L, Hass E, Overbeck S, Thomsen J, et al. Commonly recommended daily intake of vitamin $D$ is not sufficient if sunlight exposure is limited. J Int Med. 2000 Feb; 247(2):260-8. PMID:10692090

6. Grant WB. In defense of the sun: An estimate of changes in mortality rates in the United States if mean serum 25-hydroxyvitamin $\mathrm{D}$ levels were raised to $45 \mathrm{ng} / \mathrm{mL}$ by solar ultraviolet-B irradiance. Dermato-Endocrinol. 2009 Jul; 1:207-14. PMID:20592792

7. Lips P. Vitamin D status and nutrition in Europe and Asia. J Steroid Biochem Mol Biol. 2007 Mar;103(3-5):620-5. PMID:17287117

8. Fields J, Trivedi NJ, Horton E, Mechanick JI. Vitamin D in the Persian Gulf: integrative physiology and socioeconomic factors. Curr Osteoporos Rep. 2011;9(4):243-50. PMID:21901427

9. Fahed AC, El-Hage-Sleiman A-KM, Farhat TI, Nemer GM Diet, genetics, and disease: a focus on the Middle East and North Africa region. J Nutr Metab. 2012;2012:109037. doi:10.1155/2012/109037.

10. Mithal A, Wahl DA, BonjourJP, Burckhardt P, Dawson-Hughes $B$, Eisman JA, et al and IOF Committee of Scientific Advisors (CSA) Nutrition Working Group. Global vitamin D status and determinants of hypovitaminosis D. Osteoporos Int. 2009 Nov;20(11):1807-20. PMID:19543765

11. El-Sonbaty MR, Abdul-Ghaffar NU. Vitamin D deficiency in veiled Kuwait women. Eur J Clin Nutr. 1996 May;50(5):315-8. PMID:8735313

12. Badawi A, Arora P, Sadoun E, Al-Thani A, Al Thani MH. Prevalence of vitamin D insufficiency in Qatar: a systematic review. J Public Health Res. 2012 Dec;1(3): 229-35. PMID:25170469

13. Al Attia HM, Ibrahim MA. The high prevalence of vitamin D inadequacy and dress style of women in the sunny UAE. Arch Osteoporos. 2012;7(1-2):307-10. PMID:23150183
14. Dawodu A, Absood G, Patel M, Agarwal M, Ezimokhai M, Abdulrazzaq $Y$ et al. Biosocial factors affecting vitamin $D$ status of women of childbearing age in the United Arab Emirates. J Biosoc Sci. 1998 Oct;30(4):431-7. PMID:9818552

15. Dawodu A, Dawson KP, Amirlak I, Kochiyil J, Agarwal M, Badrinath P. Diet, clothing, sunshine exposure and micronutrient status of Arab infants and young children. Ann Trop Paediatr. 2001 Mar;21(1):39-44. PMID:11284245

16. Dawodu A, Agarwal M, Hossain M, Kochiyil J, Zayed R. Hypovitaminosis $\mathrm{D}$ and vitamin $\mathrm{D}$ deficiency in exclusively breastfeeding infants and their mothers in summer: a justification for vitamin $D$ supplementation of breast-feeding infants. J Pediatr. 2003 Feb;142(2):169-73. PMID:12584539

17. Saadi HF, Nagelkerke N, Benedict S, Qazaq HS, Zilahi E, Mohamadiyeh MK, et al. Predictors and relationships of serum 25 hydroxyvitamin D concentration with bone turnover markers, bone mineral density, and vitamin $D$ receptor genotype in Emirati women. Bone. 2006 Nov;39(5):1136-43. PMID:16814623

18. Dawodu A, Kochiyil J, Altaye N. Pilot study of sunlight exposure and vitamin D status in Arab women of childbearing age. East Mediterr Health J. 2011 Jul;17(7):570-4. PMID:21972479

19. Laleye LC, Kerkadi AH, Wasesa AA, Rao MV, Aboubacar A. Assessment of vitamin $D$ and vitamin $A$ intake by female students at the United Arab Emirates University based on self-reported dietary and selected fortified food consumption. Int J Food Sci Nutr. 2011 Jun;62(4):370-6. PMID:21126211

20. Rajah J, Haq A, Pettifor JM. Vitamin D and calcium status in urban children attending an ambulatory clinic service in the United Arab Emirates. Dermato-endocrinol. 2012 Jan;4(1):39-43. PMID:22870351

21. Al-Anouti F, Al-Ameri S, Thomas J, Abdel-Wareth L, Devkaran $S$, Rajah J, et al. Sun avoidance among indoor employees leading to vitamin $\mathrm{D}$ deficiency and depression in the United Arab Emirates. Int J Med Med Sci. 2013 Dec;5:503-9.

22. Haq A, Rajah J, Abdel-Wareth LO. Vitamin D: measurement, deficiency, and its health consequences. Middle East Lab. 2009 12(1):6-10.

23. Muhairi SJ, Mehairi AE, Khouri AA, Naqbi MM, Maskari FA, Al Kaabi J, et al. Vitamin D deficiency among healthy adolescents in Al Ain, United Arab Emirates. BMC Public Health. 2013 Jan 14:13:33. PMID:23311702

24. Kennel KA, Drake MT, Hurley DL. Vitamin D deficiency in adults: when to test and how to treat. Mayo Clin Proc. 2010 Aug;85(8):752-7. PMID:20675513 